\title{
Analisis Penerapan Hukum Terhadap Putusan Hakim dalam Perkara Tindak Pidana LGBT di Lingkungan Tentara Nasional Indonesia
}

\section{Law Application Analysis of the Judge's Ruling on LGBT Crimes in The TNI Neighborhood}

\author{
M. Jalil Sembiring, Mahmud Mulyadi \& Isnaini* \\ Program Studi Magister Ilmu Hukum Universitas Medan Area Indonesia \\ Diterima: 02 Juni 2021 Direview: 02 Juni 2021; Disetujui: 28 September 2021 \\ *Coresponding Email: isnaini@staff.uma.ac.id
}

\begin{abstract}
Abstrak
Penelitian ini bertujuan untuk menganalisa putusan hakim nomor perkara 115-K/PM.1-02/AD/X/2019 di Pengadilan Militer I-02 Medan tentang beda pendapat majelis hakim perkara Gay Biseksual dan Transgender (LGBT) di lingkungan Tentara Nasonal Indonesia (TNI). Tujuan penelitian ini untuk mengkaji peraturan hukum tentang penghukuman pidana bagi pelaku LGBT di lingkungan TNI dan mengkaji penerapan hukuman bagi pelaku yang melanggar larangan LGBT di lingkungan TNI, sekaligus menganalisis bagaimana Dasar penerapan hukum terhadap prajurit yang melakukan pelanggaran LGBT di lingkungan TNI. Penelitian yang dilakukan ialah penelitian hukum normatif yang menggunakan pendekatan yuridis normatif yang mengambil data sekunder dengan membuat dari bahan hukum primer, bahan hukum sekunder dan bahan hukum tersier. Berdasarkan hasil penelitian dapat diketahui bahwa LGBT merupakan perilaku yang sangat menyimpang yang mana Indonesia belum ada peraturan perundang-undang yang mengatur tentang perbuatan LGBT secara umum dan khusus sehingga penerapan hukuman berdasarkan pada Pasal 281 KUHP, Pasal 103 KUHPM, Peraturan Pemerintah Nomor 39 Tahun 2010 Pasal 53 Ayat (1) huruf b Tentang Administrasi Prajurit Tentara Nasional Indonesia, Keputusan Kasad Nomor Kep/330/IV/2018 Tanggal 17 April 2018 tentang Pemberhentian dengan tidak hormat dilingkungan TNI, yang diberlakukan untuk menjerat pelaku LGBT di Lingkungan TNI.
\end{abstract}

Kata Kunci: Penerapan Pidana; Lesbian Gay Biseksual dan Transgender; Lingkungan Tentara Nasional Indonesia.

\begin{abstract}
This study aims to analyze the judge's decision on case number 115-K/PM.1-02/AD/X/2019 at the Military Court I-02 Medan about the different opinions of the panel of judges in the Gay Bisexual and Transgender (LGBT) case in the Indonesian National Army (TNI). TNI). The purpose of this study is to examine the legal regulations regarding criminal punishment for LGBT perpetrators within the TNI and examine the application of penalties for perpetrators who violate the LGBT prohibition within the TNI, as well as to analyze how the basis for applying the law to soldiers who commit LGBT violations within the TNI is. The research conducted is normative legal research that uses a normative juridical approach that takes secondary data by making primary legal materials, secondary legal materials and tertiary legal materials. Based on the results of the study, it can be seen that LGBT is a very deviant behavior in which Indonesia has no laws and regulations governing LGBT acts in general and specifically so that the application of punishment is based on Article 281 of the Criminal Code, Article 103 of the Criminal Code, Government Regulation Number 39 of 2010 Article 53 Paragraph (1) letter b Concerning Administration of Indonesian National Armed Forces Soldiers, Kasad Decree Number Kep/330/IV/2018 dated 17 April 2018 concerning Disrespectful Dismissal within the TNI, which was imposed to ensnare LGBT perpetrators within the TNI. Keywords: Criminal Application; Lesbian Gay Bisexual and Transgender; Indonesian National Armed Forces Environment.
\end{abstract}

How to Cite: Sembiring, M.J. Mulyadi, M. \& Isnaini. (2021). Analisis Penerapan Hukum Terhadap Putusan Hakim dalam Perkara Tindak Pidana LGBT di Lingkungan Tentara Nasional Indonesia. Journal of Education, Humaniora and Social Sciences (JEHSS). 4(2): 863-874. 


\section{PENDAHULUAN}

Negara Indonesia adalah Negara yang berdasarkan atas hukum (rechtsstaat), Pernyataan tersebut secara tegas tercantum dalam Undang-Undang Dasar 1945. Sebagai Negara hukum Indonesia menerima hukum sebagai ideologi untuk menciptakan ketertiban, keamanan, keadilan serta kesejahteraan bagi warga negaranya. Konsekuensi dari itu semua adalah bahwa hukum mengikat setiap tindakan yang dilakukan oleh warga Negara Indonesia. Hukum sebagai konfigurasi peradaban manusia berjalan seiring dengan pertumbuhan dan perkembangan masyarakat sebagai komunitas di mana manusia tumbuh dan berkembang pula. Namun belakangan ini, terjadi berbagai distorsi perubahan dalam masyarakat Indonesia yang kemudian dikenal sebagai krisis moral.

Salah satu perubahan di masyarakat dapat dikategorikan sebagai salah satu krisis moral adalah perbuatan atau prilaku penyimpangan seks diantaranya lesbian, gay, biseksual, dan transgander atau yang sering disebut dengan istilah LGBT. Gambaran umum tentang prilaku penyimpangan seks LGBT di Indonesia, dalam hukum nasional tidak diberi ruang bagi kelompok LGBT. Hukum Indonesia hanya mengakui keberadaan gender laki-laki dan perempuan saja, sehingga orang transgender yang tidak memilih untuk menjalani operasi perubahan kelamin, dapat mengalami masalah dalam pengurusan dokumen identitas dan hal lain yang terkait. Sejumlah Perda melarang homoseksualitas sebagai tindak pidana karena dipandang sebagai perbuatan yang tidak bermoral, meskipun Perda yang terkait tidak secara tegas mengatur hukumannya. (Rahmi, 2018; Sigiro dkk, 2020).

Perbuatan penyimpangan seks diantaranya lesbian, gay, biseksual, dan transgander atau yang sering disebut dengan istilah LGBT, berdasarkan hasil data dan referensi menunjukan semakin bertambah dan terus meninggi jumlahnya di Indonesia tidak terkecuali di lingkungan Tentara Nasional Indonesia (TNI). Keberadaan LGBT di Indonesia menjadi kontroversi di negara yang mayoritas muslim serta menjunjung nilai moral yang tinggi. (Marlina, 2015; Simanjuntak dkk, 2010)

Banyaknya kasus LGBT di Indonesia tidak menutup kemungkinan terjadi di lingkungan TNI, faktanya terdapat beberapa kasus personil militer yang kerap menjadi seorang LGBT. Hal ini sangat bertentangan dengan norma-norma di lingkungan TNI yang mana perbuatan ini dapat merusak martabat dan nama baik TNI. Tidak adanya aturan khusus mengenai LGBT di Indonesia baik di lingkungan TNI maupun masyarakat biasa sehingga dalam kasus ini lingkungan TNI berpedoman pada Pasal 103 KUHPM dan pasal 281 KUHP sebagai dasar hukum yang digunakan Hakim dalam memutus perkara LGBT di lingkungan TNI.

Seorang TNI sebagai pelaku LGBT harus ditindaklanjuti sebagaimana ketentuan-ketentuan yang berlaku di Lingkungan TNI. Seorang militer yang telah melakukan perilaku LGBT dapat diminta pertanggungjawaban pidana berupa hukuman yang terdapat dalam Pasal 103 KUHPM berupa pemecatan dan pidana penjara. Pertanggungjawaban secara umum adalah merupakan bentuk tanggung jawab seseorang atas tindakan yang dilakukannya. Sedangkan untuk pertanggungjawaban pidana merupakan bentuk pemidanaan pelaku dengan maksud untuk menentukan apakah seseorang tersangka dapat dipertanggungjawabkan atas suatu tindakan pidana yang terjadi atau tidak.

Belum ada satupun pasal di kitab perundang-undangan di negera Indonesia ini yang memperbolehkan atau sekedar mengisyaratkan pembolehan seks sesama jenis, justru aktivitas LGBT melanggar hak asasi orang lain untuk mendapatkan kebutuhan seks sesama jenis sebagaimana kodratnya dan melanggar hak asasi orang lain untuk mendapatkan keturunan.

Perbedaan pendapat sangat dimungkinkan terjadi sebagai konsekuensi pelaksanaan persidangan dengan susunan hakim majelis. Dalam pemeriksaan perkara pidana di pengadilan pada asasnya persidangan untuk semua pengadilan adalah majelis. Semua pengadilan memeriksa dan memutus perkara dengan sekurang-kurangnya tiga orang hakim, kecuali apabila undangundang menentukan lain. Di antara para hakim tersebut, seorang bertindak sebagai Ketua, dan lainnya sebagai Hakim Anggota sidang. Sebagai konsekuensi logis terhadap susunan persidangan 
dengan model majelis hakim ini maka perbedaan pendapat diantara anggota majelis hakim dalam memutuskan perkara di persidangan sangat mungkin terjadi.

Penelitian Wendi Muhammad, Universitas Muhammadiyah Sumut, 1606200339, dengan judul skripsi "Penghukuman bagi pelaku LGBT di lingkungan TNI". Permasalahan yang dibahas adalah pengaturan hukum larangan tentang LGBT di lingkungan TNI. Penerapan hukuman bagi pelaku yang melanggar larangan LGBT di lingkungan TNI dan putusan nomor perkara 114-K/PM.1-02/AD/X/2019 Pengadilan Militer 1-02 Medan. Penelitian Romi Saputra, Universitas Islam Negeri Sulthan Thata Saifuddin SPI 141864 dengan judul Skripsi "Putusan mahkamah konstitusi no 46/PUU-XIV/2016 ini mengenai LGBT dan kumpul kebo ditinjau dari Hukum Nasional". Permasalahan yang dibahas adalah: dasar putusan Mahkamah Konstitusi menolak permohonan uji materi pasal 284, 285, dan 292 dalam putusan No 46/PUU_XIV/2016 tentang LGBT dan Kumpul Kebo. Putusan Mahkamah Konstitusi No 46/PUU_XIV/2016 sudah sesuai dengan kewenangan Mahkamah Konstitusi.

Dari judul penelitian dan permasalahan tersebut di atas, tidak ada kesamaan yang menyangkut dengan penelitian yang dilakukan. Dengan demikian judul "Analisis penerapan hukum terhadap putusan hakim dalam perkara tindak pidana LGBT dilingkungan TNI" belum pernah dilakukan, sehingga keaslian penelitian di Pengadilan Militer 1-02 Medan dapat dipertanggungjawabkan secara ilmiah.

\section{METODE PENELITIAN}

Jenis penelitian ini menggunakan penelitian hukum yuridis normatif atau doktriner yang juga disebut sebagai penelitian perpustakaan atau studi dokumen, karena lebih banyak dilakukan terhadap data yang bersifat sekunder yang ada di perpustakaan. Penelitian hukum normatif atau doktriner yang diajukan dalam kajian ini adalah penelitian terhadap asas-asas hokum. Sedangkan sifat penelitian ini adalah deskriptif Analis, yang dari hasil ini dapat mendeskripsikan secara menyeluruh dan sistematis mengenai penegakan hukum dilingkungan peradilan Militer terhadap pelaku tindak pidana LGBT dengan menggunakan penelitian hukum normatif, yaitu penelitian yang ditujukan hanya pada peraturan-peraturan tertulis, bahan-bahan hukum lainnya.

Pendekatan-pendekatan yang digunakan di dalam penelitian hukum adalah pendekatan undang-undang, pendekatan kasus. Pendekatan undang-undang dilakukan dengan menelaah semua undang-undang dan regulasi yang bersangkut paut dengan isu hukum yang ditangani, Pendekatan kasus dilakukan dengan cara melakukan telaah kasus-kasus yang berkaitan dengan putusan Pengadilan Militer I-02 Medan yang telah mempunyai kekuatan hukum tetap. Pendekatan dalam penelitian ini adalah menggunakan pendekatan undang-undang dan juga kasus berdasarkan data-data yang yang diperoleh dari Pengadilan Militer I-02 Medan.

Penelitian dilakukan di Pengadilan Militer I-02 Medan serta instansi yang terkait dengan alasan sebagai bahwa sangat memungkinkan Pengadilan Militer I-02 Medan dapat mendukung data dalam penelitian, Penelitian berdomisili di Kodam I/BB yang berada diwilayah hukum Pengadilan Militer I-02 Medan, Kondisi Pengadilan Militer I-02 Medan dapat terjangkau oleh peneliti sehingga memungkinkan untuk mendapatkan data yang lebih baik dan Pengadilan Militer I-02 Medan sebagai sumber data sesuai dengan penelitian yang dimaksud.

Sumber Data dalam dalam penelitian ini terdiri dari bahan hukum primer, sekunder dan tersier. Bahan hukum primer, bersumber dari bahan hukum yang diperoleh langsung dan akan digunakan dalam penelitian yang merupakan bahan hukum yang mempunyai kekuatan mengikat secara yuridis, Bahan hukum sekunder merupakan bahan hukum yang erat hubungannya dengan bahan hukum primer yang dapat membantu menganalisa serta memahami bahan-bahan sekunder. Bahan hukum tersier, bahan hukum yang memberikan petunjuk atau penjelasan yang bermakna terhadap bahan hukum primer dan sekunder berupa kamus umum, kamus hukum, majalah, surat kabar dan jurnal-jurnal hukum.

Teknik pengumpulan data dilakukan melalui Penelitian kepustakaan (Library Research) yaitu dengan mengumpulkan dan mempelajari serta menganalisa konsep-konsep, teori-teori 
pendapat-pendapat atau penemuan-penemuan serta ketentuan perundang-undangan yang berkaitan dengan hukum. Dokumentasi sebuah acara yang dilakukan untuk menyediakan dokumen-dokumen dengan menggunakan bukti yang akurat dari pencatatan sumber-sumber informasi khusus dari karangan/tulisan,buku,undang-undang dan sebagainya. Wawancara merupakan percakapan antara dua orang atau lebih dan berlangsung antara sumber dan pewawancara. Tujuan wawancara adalah untuk mendapatkan informasi yang tepat dari narasumber yang terpercaya. Pada Kesempatan ini wawancara dilakukan dengan mejelis hakim Pengadilan Militer I-02 Medan yang menangani kasus tindak pidana LGBT.

Analisis data dalam penelitian hukum ini mempergunakan metode deskriptif kualitatif, karena tanpa menggunakan rumusan statistik, sedangkan penggunaan angka-angka hanya sebatas angka presentase sehingga diperoleh gambaran yang jelas dan menyeluruh mengenai masalah yang diteliti. Penelitian kualitatif yaitu mendeskripsikan serta menjelaskan data yang diperoleh selama penelitian diproses dengan analisa dan teknik yang digunakan sesuai tahapan pengumpulan data, reduksi data dan sajian serta kesimpulan.

\section{HASIL DAN PEMBAHASAN}

\section{Pengaturan Hukum bagi Hakim dalam Membuat Putusan terhadap Perkara Tindak Pidana LGBT di Lingkungan TNI.}

Perlakuan seks menyimpang LGBT merupakan suatu tindak pidana dan pelanggaran yang merupakan krisis moral dilingkungan prajurit TNI, baik terhadap prajurit itu sendiri maupun terhadap kesatuan dan juga terhadap masyarakat di sekitar secara sosial, maka dengan pendekatan teoritis, penyebab dari Perlakuan seks menyimpang LGBT adalah merupakan delik materil, sedangkan perbuatannya untuk dituntut pertanggungjawaban pelaku, merupakan delik formil. Perlakuan seks menyimpang LGBT adalah suatu kondisi yang dapat dikonseptualisasikan sebagai suatu gangguan jiwa, yaitu gangguan mental dan perilaku akibat Perlakuan seks menyimpang LGBT.

Maraknya kasus LGBT di Indonesia tidak menutup kemungkinan terjadi di lingkungan TNI, faktanya terdapat beberapa kasus personil militer yang kerap menjadi seorang LGBT. Hal ini sangat bertentangan dengan norma-norma di lingkungan TNI yang mana perbuatan ini dapat merusak martabat dan nama baik TNI. Tidak adanya aturan khusus mengenai LGBT di Indonesia baik di lingkungan TNI maupun masyarakat biasa sehingga dalam kasus ini lingkungan TNI berpedoman pada Pasal 103 KUHPM dan pasal 281 KUHP sebagai dasar hukum yang digunakan Hakim dalam memutus perkara LGBT di lingkungan TNI.

Seorang TNI sebagai pelaku LGBT harus ditindaklanjuti sebagaimana ketentuan-ketentuan yang berlaku di Lingkungan TNI. Seorang militer yang telah melakukan perilaku LGBT dapat diminta pertanggungjawaban pidana berupa hukuman yang terdapat dalam Pasal 103 KUHPM berupa pemecatan dan pidana penjara.

Eksistensi putusan hakim atau lazim disebut dengan terminologi "putusan pengadilan" sangat diperlukan untuk menyelesaikan perkara pidana/perdata. Oleh karena demikian diharapkan para pihak, baik Penggugat/Pelapor maupun Tergugat/Terlapor dapat menerima putusan sehingga orang yang "merasa" dan "dirasa" haknya telah dilanggar oleh orang lain mendapatkan haknya kembali dan orang yang "merasa" dan "dirasa" telah melanggar hak orang lain harus mengembalikan hak tersebut.

Apabila Majelis Hakim telah memeriksa suatu perkara yang diajukan kepadanya, mereka harus menyusun putusan dengan baik dan benar. Untuk mengakhiri perkara/sengketa yang diajukan, putusan tersebut harus diucapkan dalam sidang terbuka untuk umum, sebagaimana disebutkan dalam Pasal 13 ayat (2) Undang-Undang Nomor 48 Tahun 2009 tentang Kekuasaan Kehakiman.

Menurut Hamzah (tahun), sebagaimana dikutip oleh Abdul Manan, putusan adalah "hasil atau kesimpulan dari perkara yang dipertimbangkan dengan masak-masak yang dapat berbentuk tertulis maupun lisan". Sudikno Martokusumo, sebagaimana juga dikemukakan oleh Abdul Manan, mendefinisikan putusan dengan "suatu pernyataan oleh Hakim sebagai pejabat negara yang diberi 
wewenang untuk itu dan diucapkan dalam sidang yang terbuka untuk umum dengan tujuan untuk menyelesaikan perkara atau sengketa antara pihak yang berperkara".

Berdasarkan kedua definisi yang dikemukakannya tersebut, Manan (tahun) menyimpulkan bahwa putusan adalah kesimpulan akhir yang diambil oleh Majelis Hakim yang diberi wewenang untuk itu dalam menyelesaikan atau mengakhiri suatu sengketa antara pihak-pihak yang berperkara dan diucapkan dalam sidang terbuka untuk umum.

Putusan pada dasarnya merupakan proses ilmiah dengan Majelis Hakim sebagai poros utamanya. Majelis Hakim memegang peranan sentral dalam membuat putusan atas memutus sengketa yang sedang ditanganinya. Implementasi hukum dalam putusan Majelis Hakim mengacu pada kerangka pikir tertentu yang dibangun secara sistematik. Doktrin atau teori hukum (legal theory) memegang peranan penting dalam membimbing Majelis Hakim menyusun putusan yang berkualitas dan mampu mengakomodir tujuan hukum, yaitu keadilan, kepastian dan kemanfaatan hukum. Ketika Hakim memeriksa dan mengadili perkara agar dapat melahirkan suatu putusan yang adil, yang berkepastian hukum dan bermanfaat.

Dalam suatu putusan, pertimbangan hukum merupakan jiwa dan intisari putusan. Pertimbangan hukum berisi analisis, argumentasi, pendapat atau kesimpulan hukum dari Majelis Hakim yang memeriksa perkara. Dalam pertimbangan hukum tersebut dikemukakan analisis yang jelas berdasarkan undang-undang pembuktian.

Selanjutnya diikuti dengan analisis, hukum apa yang diterapkan menyelesaikan perkara tersebut. Bertitik tolak dari analisis itu, pertimbangan melakukan argumentasi yang objektif dan rasional, pihak mana yang mampu membuktikan dalil gugat atau dalil bantahan sesuai dengan ketentuan hukum yang diterapkan. Dari hasil argumentasi itulah Majelis Hakim menjelaskan pendapatnya apa saja yang terbukti dan yang tidak, dirumuskan menjadi kesimpulan hukum sebagai dasar landasan penyelesaian perkara yang akan dituangkan dalam diktum putusan.

Apabila putusan tidak lengkap dan saksama mendeskripsikan dan mempertimbangkan alat bukti dan nilai kekuatan pembuktian, mengakibatkan putusan dianggap tidak cukup pertimbangan hukumnya atau onvoldoende gemotiveerd, dan putusan tersebut bertentangan dengan Pasal 178 ayat (1) HIR, Pasal 189 RBG dan Pasal 14 ayat (2) Undang-Undang Nomor 48 Tahun 2009 tentang Kekuasaan Kehakiman.

Dengan demikian dapat disimpulkan bahwa dalam suatu putusan Majelis Hakim harus mengemukakan analisis, argumentasi, pendapat, kesimpulan hukum, dan harus pula memuat alasan dan dasar putusan, juga memuat pasal tertentu dari peraturan perundang-undangan yang bersangkutan atau sumber hukum tak tertulis yang dijadikan dasar untuk mengadili.

Dalam mengambil putusan, masing-masing Hakim mempunyai hak yang sama dalam melakukan tiga tahap yang mesti dilakukan Hakim untuk memperoleh putusan yang baik dan benar.

Pertama, tahap konstatir. Mengonstatir peristiwa hukum yang diajukan oleh para pihak kepadanya dengan melihat, mengakui atau membenarkan telah terjadinya peristiwa yang telah diajukan tersebut. Jadi, mengkonstatir berarti bahwa Hakim melihat, mengetahui, membenarkan, telah terjadinya peristiwa, harus pasti bukan dugaan, yang didasarkan alat bukti pembuktian. 1) Proses pembuktian dimulai meletakkan beban bukti yang tepat, kepada siapa beban bukti ditimpakan. Menilai alat bukti yang diajukan, apakah alat bukti tersebut memenuhi syarat formil, syarat materil, memenuhi batas minimal bukti serta mempunyai nilai kekuatan pembuktian. 2) Menentukan terbukti atau tidak/dalil peristiwa yang diajukan. Bagi Hakim yang penting fakta peristiwa, bukan hukumnya. Pembuktian adalah ruh bagi putusan Hakim.

Kedua, tahap kualifisir. Mengkualifisir peristiwa hukum yang diajukan pihak-pihak kepadanya. Peristiwa yang telah dikonstatirnya itu sebagai peristiwa yang benar-benar terjadi harus dikualifisir. Mengkualifisir berarti menilai peristiwa yang dianggap benar-benar terjadi itu termasuk hubungan hukum mana dan hukum apa, dengan kata lain harus ditemukan hubungan hukumnya bagi peristiwa yang telah dikonstatir itu. Jadi, mengkualifisir berarti mencari/menentukan hubungan hukum terhadap dalil/peristiwa yang telah dibuktikan. Hakim menilai terhadap dalil/peristiwa yang telah terbukti atau menilai dalil/peristiwa yang tidak 
terbukti dengan peraturan perundang-undangan yang merupakan hukum materil atau dapat dikatakan mencari penerapan hukum yang tepat terhadap dalil/peristiwa yang telah dikonstatir.

Ketiga, tahap konstituir. Mengkonstituir, yaitu menetapkan hukumnya atau memberikan keadilan kepada para pihak yang berperkara.

Berdasarkan uraian di atas, jika tahap yang harus dilalui seorang Hakim untuk membuat putusan di atas (konstatir, kualifisir dan konstituir) dijadikan alat ukur untuk menilai pertimbangan hukum suatu putusan, maka dapat disimpulkan apabila Hakim tidak melakukan salah satu proses dari tahapan tersebut atau gagal melakukan, misalnya Hakim tidak berhasil melakukan tahap konstatir, karena tidak menetapkan beban pembuktian dan tidak menilai alat bukti, atau tidak berhasil melakukan tahap kualifisir, karena tidak menyimpulkan mana fakta hukum yang terbukti dan apa saja dasar hukum yang berkaitan dengan pokok perkara. Ketidak berhasilan pada dua tahap sebelumnya di atas, sangat berpotensi mengakibatkan ketidak berhasilan dalam dalam menjatuhkan amar putusan yang merupakan tahap konstituir ini.

Untuk menghasilkan putusan yang baik dan memberikan rasa keadilan, kepastian dan manfaat kepada para pihak yang berperkara, marilah kita aplikasikan dan terapkan tahap-tahap dalam membuat dan menetapkan suatu putusan sebagaimana yang telah dipaparkan di atas.

Di dalam KUHAP sendiri hakim yang diucapkan dalam sidang yang terbuka, yang dapat berupa pemidanaan atau bebas atau lepas dari segala tuntutan hukum dalam hal serta menurut cara yang diatur dalam Undang-undang ini. Sedangkan untuk jenis putusan sendiri ada dua jenis yaitu putusan sela dan putusan akhir. Perbedaan dari keduanya terletak pada sejauh manakah suatu perkara pidana telah diperiksa oleh hakim.

Dari penjelasan diatas maka dapat kita ketahui bahwa sesungguhnya pemidanaan adalah suatu proses penjatuhan sanksi pidana yang ada didalam undang-undang oleh hakim kepada terdakwa di dalam putusan yang di buat olehnya. Selanjutnya pengertian tujuan pemidanaan sendiri merupakan apa yang di harapkan untuk di capai dari penjatuhan putusan pidana.

Tujuan pemidanaan itu sendiri telah berkembang dimana saat ini telah menjurus ke arah yang lebih rasional dan manusiawi. Sistem pemidanaan pun mulai mengarah pada suatu perkembangan bahwa penjatuhan pidana bukan hanya semata-mata sebagai pembalasan tetapi lebih mengutamakan unsur mendidik dan memberikan kesempatan bagi seorang terpidana untuk memperbaiki dirinya sendiri dengan memberikan pendidikan moral dan kesempatan untuk berubah dan berprilaku baik bagi para pelaku kejahatan.

Tujuan pidana yang berlaku sekarang ialah variasi dari bentuk-bentuk penjeraan (deterrent), baik ditujukan kepada pelanggar hukum sendiri maupun kepada mereka yang mempunyai potensi untuk menjadi jahat, perlindungan kepada masyarakat dari perbuatan jahat dan perbaikan (reformasi) kepada penjahat, tujuan inilah yang paling modern dan populer dewasa ini, bukan saja bertujuan memperbaiki pemenjaraan tapi juga mencari alternatif lain yang bukan bersifat pidana dalam membina pelanggar hukum.

Adapun dalam tujuan dari pemidanaan itu sendiri ada berbagai macam teori dan pendapat, namun dari sekian banyak teori yang ada tersebut itu dapat digolongkan menjadi 3 kelompok besar, yaitu : 1) Teori absolut atau teori pembalasan (vergeldings theorien) Menurut teori ini pidana tidaklah bertujuan untuk yang praktis, seperti memperbaiki penjahat. Pidana dijatuhkan semata-mata karena orang telah melakukan suatu kejahatan atau tindak pidana. Pidana merupakan akibat mutlak yang harus ada sebagai suatu pembalasan kepada orang yang melakukan kejahatan. Jadi dasar pembenaran dari pidana terletak pada adanya atau terjadinya kejahatan itu sendiri. 2) Teori relatif atau teori tujuan (doel theorien) Teori relatif atau Teori tujuan Menurut teori ini memidanakan bukanlah untuk memuaskan tuntutan absolut dari keadilan. Pembalasan itu sendiri tidak mempunyai nilai, tetapi hanya sebagai sarana untuk melindungi kepentingan masyarakat. Oleh karena itu, J.Andeanaes berpendapat teori ini dapat disebut teori perlidungan masyarakat (the theory of sosial defence). Sementara itu untuk pencegahan dalam teori ini dibagi menjadi dua macam yaitu: pencegahan umum (general preventie) dan pencegahan khusus (speciale preventie). Prevensi umum menghendaki agar orang-orang pada umumnya takut melakukan delik, yang dilaksanakan dengan cara yang menakutkan masyarakat. Prevensi khusus bertujuan untuk mencegah niat buruk pelaku dan mencegah pelanggar mengulangi perbuatannya 86ु http://mahesainstitute.web.id/ojs2/index.php/jehss 
atau mencegah bakal pelanggar melakukan perbuatan jahat yang direncanakannya. 3) Teori Gabungan (vernengings theorien) Teori ini merupakan perpaduan antara dua teori sebelumnya yang intinya adalah bahwa hukuman pidana bertujuan membalas kesalahan dan mengamankan kehidupan masyarakat dengan memberikan perlindungan kepada masyarakat yang diterapkan secara kombinasi dengan menitik beratkan pada salah satu unsur namun tidak berarti menghilangkan unsur lainnya. 4) Pidana Bersyarat sebagai alternatif Pemidanaan.

Pengertian pidana bersyarat itu sendiri terdapat beberapa pendapat di kalangan para ahli hukum antara lain, diantaranya pendapat P.A.F. Lamintang yang menyebutkan: Pidana bersyarat adalah suatu pemidanaan yang pelaksanaannya oleh hakim telah digantungkan pada syarat-syarat tertentu yang ditetapkan dalam putusannya. Pengaturan mengenai pidana bersyarat ini sendiri di dalam KUHP terdapat pada Pasal 14a-14 f KUHP. Walaupun disebut sebagai pidana bersyarat, pidana bersyarat bukanlah merupakan salah satu dari jenis pidana sebagaimana yang tercantum dalam pasal 10 KUHP. Oleh sebab itu pidana bersyarat lebih cocok disebut sebagai sistem pemidanaan tertentu (Penjara) dimana ditetapkan dalam amar putusan bahwa pidana yang dijatuhkan tersebut tidak perlu dijalankan oleh terdakwa dengan syarat-syarat tertentu yang telah ditetapkan hakim.

Dalam penerapan pidana bersyarat itu sendiri tercakup suatu hal yang sangat penting yakni manfaat yang diharapkan dari sanksi pidana bersyarat. Pidana bersyarat diharapkan dapat menjadi suatu kemungkinan pilihan (Alternatif Pemidanaan) yang sangat berguna dalam rangka rehabilitasi, khususnya bagi pelaku-pelaku tindak pidana pemula yang melakukan kejahatan bukan karena sifat jahat dari dirinya melainkan karena adanya faktor-faktor yang membuatnya terpaksa melakukan kejahatan tersebut. Pergaulan dan hubungan sosial yang teratur dalam masyarakat akan menghindarkan adanya stigma (cap jahat) dari masyarakat terhadap pelaku tindak pidana (bekas narapidana) yang telah di Penjara. Oleh sebab itu penerapan pidana bersyarat tidak terlepas dari peranan hakim yang juga sangat penting dalam menjatuhkan putusan.

Seorang hakim dalam menjatuhkan putusan dituntut untuk bisa memenuhi rasa keadilan masyarakat dengan tidak hanya berpedoman pada hukum yang tertulis, tetapi juga hukum yang tidak tertulis atau kebiasaan yang berlaku dalam masyarakat tersebut. Sehingga seorang hakim tidak hanya menjadi corong undang-undang semata tetapi juga harus memperhatikan perkembangan rasa keadilan yang ada di dalam masyarakat saat ini hal ini dikarenakan rasa keadilan dalam masyarakat itu sendiri bersifat dinamis dan terus berkembang dari waktu ke waktu sehingga sebagai aparat penegak hukum hakim dituntut untuk ikut berperan dalam reformasi pembaharuan hukum demi terpenuhinya keadilan di dalam masyarakat.

\section{Analisa hasil putusan nomor 115-K/PM.I-02/AD/X/2019 Pengadilan Milter I-02 Medan}

Terdakwa masuk menjadi prajurit TNI AD pada tahun 2012 melalui pendidikan Akademi Militer di Magelang, setelah lulus dilantik dengan pangkat Letda kemudian mengikuti pendidikan Sarcab Bekang di Bandung, setelah selesai ditugaskan di Bekangdam l/BB sampai sekarang telah berpangkat Lettu NRP 1234567890 dengan jabatan sebagai Kaurkanpermin Sibek. Terdakwa pada bulan Desember tahun 2014 berkenalan dengan Saksi-2, Pulpen (disamarkan) melalui Media Sosial aplikasi Bigo Live di Handphone, dari perkenalan tersebut hubungan antara Terdakwa dengan Saksi-2 menjadi akrab dan timbul rasa saling menyukai.

Pada bulan November tahun 2015 sekira pukul 19.00 WIB, Terdakwa menjemput Saksi-2 ke rumahnya dengan menggunakan mobil Toyota Vios milik Terdakwa kemudian berangkat menuju Merdeka Walk dan nongkrong di restoran Jala-Jala, selanjutnya pada sekira pukul 24.00 WIB karena sudah larut malam maka Saksi-2 menginap di rumah Terdakwa di Perumahan Tepbek Jln. Gaperta Gg. Gudang II No. 4 Helvetia Medan dan tidur sekamar dengan Terdakwa, selanjutnya pada sekira pukul $04.00 \mathrm{WIB}$, Terdakwa merasakan ada yang memeluk dari belakang sambil mencium pipi sebelah kanan, kemudian Terdakwa terbangun dan terkejut karena yang memeluk dan mencium adalah Saksi-2, selanjutnya Saksi-2 merayu dan membujuk Terdakwa untuk melakukan 
hubungan seksual sesama jenis dengan Terdakwa namun ditolak oleh Terdakwa, tetapi Saksi-2 berusaha terus membujuk dan merayu sehingga Terdakwa mau menuruti kemauan Saksi-2.

Terdakwa dan Saksi-2 melakukan hubungan seksual sesama jenis dengan cara, pakaian Terdakwa dibuka oleh Saksi-2 kemudian Saksi-2 membuka pakaiannya sendiri, setelah samasama telanjang maka Terdakwa disuruh terlentang kemudian Saksi-2 dengan posisi di atas memasang kondom pada kemaluannya yang sudah tegang lalu memasukkan kemaluannya ke dalam anus/dubur Terdakwa sehingga Terdakwa merasa sakit pada anus Terdakwa, setelah itu Saksi-2 menggerakkan pantatnya dengan cara digoyang turun naik, selanjutnya Terdakwa dan Saksi-2 berciuman bibir dan tangan Saksi-2 meraba-raba dada Terdakwa, setelah lebih kurang 10 menit Saksi-2 mencapai klimaks/orgasme lalu mengeluarkan penisnya dari anus Terdakwa kemudian melepaskan kondom dan mengeluarkan spermanya di atas perut Terdakwa, setelah itu Saksi-2 menghisap dan mengocok alat kelamin Terdakwa hingga mengeluarkan Sperma.

Pada tahun 2016 sekira pukul 19.00 WIB Terdakwa menjumpai Saksi-2 di Hotel Cambridge Medan dalam acara ulang tahun teman Saksi-2, selanjutnya Terdakwa, Saksi-2 dan teman-teman Saksi-2 berbincang-bincang sambil meminum minuman beralkohol hingga Terdakwa terlelap ketiduran, kemudian pada sekira pukul 03.00 WIB Terdakwa terbangun dari tidur dan melihat teman-teman Saksi-2 sudah tidak ada di kamar Hotel sedangkan pakaian Terdakwa sudah terlepas (dalam keadaan telanjang), selanjutnya Saksi-2 merayu dan membujuk Terdakwa untuk melakukan hubungan seksual namun ditolak oleh Terdakwa, tetapi Saksi-2 berusaha terus membujuk dan merayu sehingga Terdakwa mau menuruti kemauan Saksi-2 dan kembali melakukan hubungan seksual sesama jenis dengan Saksi-2 untuk yang kedua kalinya.

Pada tahun 2017 di kamar Hotel Aryaduta Medan, Terdakwa dan Saksi-2 kembali melakukan hubungan seksual sesama jenis dengan untuk yang ketiga kalinya yang dilakukan dengan cara yang sama pada saat Terdakwa dan Saksi-2 pertama kali melakukan hubungan seksual sesama jenis (homoseksual).

Pada hari Selasa tanggal 23 Oktober 2018 sekira Pukul 09.00 WIB Terdakwa bersama dengan Saksi-2 pergi ke Pulau Bali menggunakan pesawat terbang dengan maksud untuk jalanjalan, setelah tiba di Pulau Bali Terdakwa dan Saksi-2 memesan sebuah kamar di Hotel The One Legian Bali, pada tanggal 26 Oktober 2018 sekira pukul 20.00 WIT Terdakwa merasa ngantuk lalu tidur karena kelelahan setelah jalan-jalan bersama Saksi-2 di wilayah Kuta Bali, sekira pukul 22.00 WIT Saksi-2 membangunkan Terdakwa lalu membujuk dan merayu Terdakwa untuk melakukan hubungan seksual, kemudian Terdakwa menuruti kemauan Saksi-2 dan kembali melakukan hubungan seksual sesama jenis untuk yang keempat kalinya.

Terdakwa mau melakukan hubungan seksual sesama jenis dengan Saksi-2 karena Saksi-2 sangat baik dan perhatian kepada Terdakwa sehingga Terdakwa merasa nyaman dan menuruti apa saja kemauan dari Saksi-2, selain itu Saksi-2 selalu memberikan perhatian dan penghiburan kepada Terdakwa apabila Terdakwa mempunyai masalah dalam keluarga Terdakwa, ibu Terdakwa sudah meninggal dunia kemudian ayah Terdakwa menikah lagi dengan wanita lain sedangkan abang Terdakwa yang juga seorang anggota TNI tetapi kemudian dipecat karena melakukan perbuatan asusila dengan isteri anggotanya.

Terdakwa mengetahui perilaku homoseksual tidak sesuai dengan kehidupan Militer dan kehidupan beragama, pelaku homoseksual gampang tertular penyakit kelamin dan HIV/AIDS dan perilaku menyimpang homoseksual akan merusak moral dan disiplin prajurit yang berpengaruh terhadap penugasannya, dan perilaku tersebut dapat menular terhadap korban-korban lainnya.

Perilaku homoseksual merupakan ancaman bagi pembinaan kekuatan satuan TNI khususnya pembinaan personel karena akan menimbulkan rasa ketakutan masyarakat khususnya Militer akan penularan perilaku homoseksual lantaran kaum homoseksual akan terus mencari penerus homoseksual, pelaku homoseksual rentan tertular penyakit kelamin dan HIV/AIDS karena suka bergonta ganti pasangan serta perilaku menyimpang homoseksual akan merusak moral dan disiplin Prajurit yang berpengaruh terhadap pelaksanaan tugas pokok TNI khususnya tugas pokok satuan, melihat akibatnya yang sangat mengerikan maka Kepala Staf Angkatan Dasar (KSAD) mengeluarkan Surat Telegram Nomor ST/1313/2009 tanggal 4 Agustus 2009 tentang larangan bagi anggota TNI untuk melakukan hubungan sesama jenis (homoseksual). 
Peraturan Pemerintah RI Nomor 39 tahun 2010 Pasal 53 Ayat (1) tentang Administrasi Prajurit TNI diatur juga mengenai larangan bagi prajurit TNI melakukan pelanggaran susila dengan jenis kelamin yang sama (homoseksual) dan bahkan di dalam Peraturan Pemerintah tersebut dinyatakan dengan tegas bahwa sanksi bagi prajurit TNI yang melanggar aturan tersebut diberhentikan tidak dengan hormat dari dinas keprajuritan.

Majelis Hakim yang memeriksa dan memutus perkara ini, tidak tercapai kata sepakat (mufakat bulat), Hakim Anggota-1, tidak sependapat dengan Hakim Ketua dan Hakim Anggota-2, oleh karena itu berdasarkan ketentuan Pasal 14 ayat (3) Undang-Undang RI Nomor 48 Tahun 2009 tentang Kekuasaan Kehakiman, pendapat Hakim yang berbeda (Dissenting Opinion) wajib dimuat di dalam putusan.

Sehingga Hakim Anggota-I, mengemukakan pendapat yang berbeda DO (Dissenting Opinion) dengan pendapat sebagaimana tersebut di atas dengan mengemukakan pendapatnya bahwa unsur-unsur tindak pidana yang terkandung dalam dakwaan alternatif kedua yaitu Pasal 281 ke1 KUHP "dengan sengaja dan terbuka melanggar kesusilaan" terbukti secara sah dan meyakinkan dengan pertimbangan hukum sebagai berikut: 1) Bahwa dengan terpenuhinya unsur "Dengan sengaja dan terbuka melanggar kesusilaan" maka semua unsur tindak pidana yang didakwakan terhadap diri Terdakwa dalam dakwaan alternatif kedua yaitu Pasal 281 ke-1 KUHP, Hakim Anggota I berpendapat terdapat cukup bukti yang sah dan meyakinkan bahwa Terdakwa bersalah telah melakukan tindak pidana "Secara terbuka melanggar kesusilaan", sebagaimana diatur dan diancam dengan pidana menurut Pasal 281 Ke-1 KUHP. 2) Bahwa dengan terpenuhinya semua unsur tersebut di atas Hakim Anggota I menemukan dua alat bukti yang sah yaitu keterangan Saksi-2 (Sdr. Indra Maulana) dan keterangan Terdakwa yang saling berhubungan dan berkaitan, dimana mengaku telah melakukan hubungan Homoseksual" dan Hakim Anggota I memperoleh keyakinan bahwa suatu tindak pidana benar-benar terjadi dan Terdakwalah pelakunya. 3) Bahwa terhadap Tuntutan (Requisitoir) Oditur Militer yang berpendapat bahwa dakwaan alternatif pertama Pasal 103 ayat (1) KUHPM adalah yang terbukti, Hakim Anggota I tidak sependapat akan keterbuktian dakwaan tersebut sehingga haruslah ditolak dan dikesampingkan. 4) Bahwa terhadap pembelaan (pledoi) Penasehat Hukum Terdakwa dalam persidangan yang berpendapat bahwa Tuntutan (Requisitoir) Oditur Militer tidak terbukti dan memohon agar Terdakwa dibebaskan dari segala tuntutan dan dakwaan Oditur Militer, Hakim Anggota I tidak sependapat terhadap pembelaan Penasihat Hukum tersebut sehingga haruslah ditolak dan dikesampingkan. 5) Bahwa perbuatan yang dilakukan oleh Terdakwa mencerminkan Terdakwa memiliki moral dan karakter yang rendah / yang buruk, perbuatan tersebut dilarang oleh pimpinan TNI karena akan sangat berdampak buruk terhadap pembinaan personel. 6) Bahwa perbuatan Terdakwa dilarang oleh agama yang ada di Indonesia dan tidak dapat diterima oleh culture (budaya) Indonesia, bertentangan dengan norma hukum, norma agama dan norma kesusilaan.

Atas pertimbangan tersebut di atas Hakim Anggota I berpendapat Terdakwa dijatuhi pidana pokok penjara selama 6 (enam) bulan dan pidana tambahan dipecat dari dinas Militer dan putusan. Sementara Hakim Ketua dan Hakim Anggota-2 Sepakat bahwa Terdakwa tidak terbukti bersalah dan Membebaskan Terdakwa dari segala dakwaan Oditur Militer sesuai dengan amar putusan hakim di atas.

Menurut penulis setelah melihat dan membaca pendapat para majelis hakim dalam menangani perkara ini, penulis sependapat dengan hasil putusan Hakim Anggota I dengan menjatuhi hukuman pidana pokok penjara selama 6 (enam) bulan dan pidana tambahan dipecat dari dinas Militer. Karena apabila pelaku LGBT dibebaskan seperti yang ada dalam putusan yang disampaikan Hakim Ketua dan Hakim Anggota II, maka akan sangat berdampak buruk terhadap pembinaan personel dilingkungan TNI.

Seperti kita ketahui bersama bahwa tindak pidana LGBT ini di Indonesia belum ada peraturan dan undang-undang secara khusus yang mengaturnya, namun demikian jangan sampai karena itu pelaku LGBT dibebaskan, terutama pelaku LGBT di lingkungan TNI. Perbuatan LGBT merupakan prilaku yang tidak layak dan tidak patut dilakukan oleh seorang Prajurit oleh karena 
itu sesuai dengan Peraturan Pemerintah RI Nomor 39 tahun 2010 Pasal 53 Ayat (1) tentang Administrasi Prajurit TNI diatur mengenai larangan bagi prajurit TNI melakukan pelanggaran susila dengan jenis kelamin yang sama (homoseksual) dan bahkan di dalam Peraturan Pemerintah tersebut dinyatakan dengan tegas bahwa sanksi bagi prajurit TNI yang melanggar aturan tersebut diberhentikan tidak dengan hormat dari dinas keprajuritan.

\section{Hambatan dan Solusi dalam Mengatasi Perkara Tindak Pidana LGBT di Lingkungan TNI}

Adanya faktor penghambat sehingga Para penegak hukum belum dapat melaksanakan perannya secara optimal, karena masih banyak hal-hal yang dihadapi dalam pelaksanaan tugas, adanya pelanggaran yang sangat tinggi dan terkesan lambat penyelesaiannya. Hambatan yang dihadapi antara lain: 1) Dislokasi Oditurat Militer dan Oditurat Militer Tinggi letaknya berjauhan dengan satuan, khususnya Odmilti yang berwenang menyidangkan Pamen hanya ada di tiga tempat yaitu, Medan, Jakarta dan Surabaya, sehingga jika terjadi ada kasus tindak pidana LGBT yang dilakukan oleh seorang pamen yang lokasinya jauh dari Odmilti harus menunggu beberapa waktu untuk dapat disidangkan. 2) Rendahnya kepedulian Para Komandan satuan ikut memonitor dan mengikuti perkembangan kasus tindak pidana LGBT yang dilakukan oleh prajuritnya yang diajukan untuk persidangan militer, namun belum semua satuan memiliki kepedulian sehingga terkesan menyerahkan sepenuhnya kepada proses peradilan. Hal ini menjadi salah satu faktor penghambat penyelesaian perkara LGBT yang diajukan ke persidangan dan disisi lain kekurang-pedulian pimpinan terhadap nasib prajurit pelanggar akan dapat menimbulkan perasaan negatif bagi prajurit terhadap satuan. 3) Dalam melakukan tugas penyidikan masih perlu ditingkatkan, karena masih ada terkesan lambat dan ragu-ragu dalam menentukan posisi kasus LGBT dan menerapkan unsur pasal yang diajukan. Hal ini akan berdampak pada berkas yang sudah dilimpahkan akan Hakim Militer harus mampu menegakkan hukum dan keadilan dengan memperhatikan kepentingan penyelenggaraan pertahanan keamanan negara, bahwa seorang hakim harus memiliki kemampuan yang memadai di bidang hukum formil dan materil serta memahami nilai-nilai tata kehidupan yang berkembang di lingkungan TNI, dikembalikan lagi ke penyidik, karena dinilai kurang memenuhi syarat formil dan materiil. 4) Lambatnya proses penyidikan, khususnya pengumpulan alat bukti dan saksi disebabkan terbatasnya dukungan dari komando atas dalam bentuk sarana dan prasarana, sehingga pemanggilan saksi dan pengumpulan alat bukti tidak segera dapat dilaksanakan.

Upaya Yang Perlu Dilakukan oleh aparat penegak hukum adanya hambatan diatas. Para penegak hukum harus mampu berperan secara optimal sehingga permasalahan hukum di wilayah Pengadilan Militer I-02 Medan dapat diselesaikan sampai tuntas dan proses penyelesaian kasus mulai tingkat penyidikan sampai keluarnya berjalan cepat sesuai dengan norma hukum dan putusan yang dijatuhkan dirasakan adil oleh prajurit. Untuk itu perlu dilakukan upaya-upaya yang sinergis agar pelanggaran dapat ditekan seminim mungkin. Antara lain : 1. Kepedulian dan peran aktif pejabat yang terkait. 2) Proses penyidikan tidak berlarut-larut. 3) Meningkatkan kerjasama yang sinergis antar para komuniti hukum. 4) Putusan Hakim setimpal dengan berat ringannya tindak pidana. 5) Meningkatkan dan mengefektifkan Jam Komandan. 6) Penyuluhan Hukum.

Pelanggaran di satuan selain perkara LGBT sampai dengan saat ini masih sangat tinggi dan Pimpinan sudah berulangkali menekankan agar menindak tegas pelaku pelanggaran dan menyelesaikan sesuai dengan proses hukum yang berlaku khususnya perkara LGBT. Putusan hukuman yang dijatuhkan belum sepenuhnya dapat memberikan efek jera kepada prajurit, sehingga pelanggaran masih terus meningkat. Para Ankum dan Papera masih perlu meningkatkan kepedulian terhadap penyelesaian kasus yang ada di satuannya. Untuk dapat menekan tingkat pelanggaran dan mencegah pelanggaran prajurit di satuan, maka perlu segera dilakukan upaya upaya yang sinergis dan berkesinambungan.

Ketua Kamar Militer Mahkamah Agung RI Mayjen (Purn) Burhan Dahlan menceritakan adanya perkara penyimpangan seksual seperti lesbian, gay, bisexual dan transgender ( $\underline{\text { LGBT }}$ ) di lingkungan Prajurit Tentara Nasional Indonesia (TNI) yang dilaporkan kepadanya. Mayjen (Purn) Burhan Dahlan mencatat, sekitar 20 (dua puluh) berkas perkara telah masuk ke Peradilan Militer. "Ada berpangkat Letnan Kolonel dokter. Ada yang baru lulusan Akademi Militer, berpangkat 
Letnan Dua," terang Mayjen (Purn) Burhan Dahlan dilansir dari tayangan langsung Youtube resmi Mahkamah Agung pada Senin (12/10/2020). Lebih lanjut, Mayjen (Purn) Burhan Dahlan menyampaikan bahwa, banyaknya anggota TNI menjadi LGBT karena faktor gaya hidup. Nantinya mereka yang ketahuan lalu diproses oleh pimpinan TNI dan diserahkan ke Pengadilan Militer dengan tuntutan Oditur Militer agar tedakwa dipecat, Kendati demikian, para terdakwa bisa bebas karena didakwa menggunakan Pasal 292 KUHP yang mengatur pencabulan orang dewasa dengan anak-anak.

Berikut bunyi Pasal 292 KUHP yang dimaksud: "Orang dewasa yang melakukan perbuatan cabul dengan orang yang belum dewasa dari jenis kelamin yang sama, sedang diketahuinya atau patut harus disangkanya hal belum dewasa itu, dihukum penjara selama-lamanya 5(lima) tahun." Mayjen (Purn) Burhan Dahlan menyatakan, Kasad Jenderal TNI Andika Perkasa, S.E., M.A., M.Sc., M.Phil., Ph.D. marah karena ada 20 (duapuluh) kasus prajurit TNI yang terlibat LGBT yang dibebaskan oleh Majelis Hakim Pengadilan Milter. Mayjen (Purn) Burhan Dahlan menilai Kasad marah dengan prajurit yang terlibat LGBT karena TNI mengemban tugas menjaga pertahanan negara. Jika dalam pelaksanaan tugas tersebut prajurit memiliki kebiasaan yang menyimpang, bagaimana prajurit bisa menjalankan tugas dengan baik. Ini sumber kemarahan Bapak Kasad. Penyampaian bapak Kasad saya limpahkan perkara prajurit yang terlibat LGBT ke pengadilan militer supaya dipecat dan dihukum supaya ada efek jera dan yang lain tidak ikut malah dibebaskan. Apa semuanya mau jadi LGBT prajurit TNI AD ini Pak Burhan?' Tanya Bapak Kasad kepada Mayjen (Purn) Burhan Dahlan sebagai Ketua Kamar Militer Mahkamah Agung Republik Indonesia.

Kemudian Mayjen (Purn) Burhan Dahlan menjelaskan kepada bapak Kasad terkait penyebab oknum TNI itu diputus bebas oleh Majelis Hakim Militer. Mayjen (Purn) Burhan Dahlan menyampaikan kepada Bapak Kasad bahwa pasal yang digunakan untuk menjerat para oknum TNI yang terlibat LGBT tersebut tidak tepat. Hal itu karena menurutnya pasal yang digunakan untuk menjerat para oknum TNI yang terlibat LGBT tersebut pasal KUHP.

Mayjen (Purn) Burhan Dahlan menyampaikan kepada Bapak Kasad, "Wajar dibebaskan Pak, Kenapa? Karena pasal yang dikenakan kepada pelaku LGBT adalah pasal yang ada di KUHP, Sementara KUHP ini belum ada pasal yang mengatur secara khusus tentang LGBT. KUHP ini belum mengatur tentang orang dewasa melakukan perbuatan cabul dengan sesama dewasa, yang ada itu adalah dilarang cabul dengan anak di bawah umur. Itu baru bisa dihukum.

Mayjen (Purn) Burhan Dahlan menambahkan lagi kepada Bapak Kasad bahwa yang ada didalam pasal 292 KUHP, Kalau seaindanya dewasa dengan dewasa, Letnan dengan Sersan, Sersan dengan prajurit, itu sudah dewasa sama dewasa tidak bisa dikenakan pasal 292 KUHP. Mayjen (Purn) Burhan Dahlan meminta para hakim agar memakai Pasal 103 KUHP Militer tentang Pembangkangan terhadap Perintah Dinas. Di mana sudah beredar ST (surat telegram) pada tahun 2009 bahwa anggota TNI dilarang menjadi homoseksual dan bagi yang terbukti homoseksual dipecat dinas militer (PDTH). Untuk para Hakim Militer, nanti saudara silakan kalau hadapi persoalan LGBT bisa sidangkan perkara ini dengan membuktikan Pasal 103 KUHPM. Hukumannya adalah tergantung saudara, ada yang bisa dipecat, ada yang tidak, tergantung kualitas perbuatannya dan fakta persidangan.

Pemecatan Dengan Tidak Hormat (PDTH) pelaku LGBT dilingkungan TNI melalui mekanisme administrasi terhadap anggota TNI yang dijatuhi pidana tambahan pecat karena terbukti terlibat LGBT, Kita bersama mengawal proses hukum anggota yang terlibat LGBT mulai dari penyidikan, penuntutan hingga putusan Pengadilan Militer guna mencegah terjadi putusan bebas terhadap pelaku LGBT dilingkungan TNI.

\section{SIMPULAN}

Pengaturan hukum larangan tentang LGBT di lingkungan TNI antara lain: 1) Hukum pidana yang berkaitan dengan LGBT di lingkungan TNI di atur dalam KUHP dan KUHPM yaitu Pasal 281 ke 1 KUHP tentang pelanggara kesusilaan dan Pasal 103 Ayat (1) KUHPM tentang ketidakpatuhan. 2) Peraturan Pemerintah Nomor 39 Tahun 2010 Pasal 53 Ayat (1) huruf b Tentang 
Administrasi Prajurit Tentara Nasional Indonesia yang menyatakan bahwa Prajurit diberhentikan tidak dengan hormat dari Dinas Keprajuritan karena mempunyai tabiat dan/atau perbuatan yang nyata-nyata dapat merugikan disiplin keprajuritan atau TNI.

Majelis Hakim berpendapat didalam putusan perkara prajurit yang terlibat LGBT dilingkungan TNI sudah tidak layak lagi untuk dipertahankan sebagai Prajurit TNI jika tidak ditindak tegas maka jelaslah akan berdampak negatif bagi upaya perbaikan citra TNI di mata masyarakat karena dapat menimbulkan gejolak dan keresahan di masyarakat dan di lingkungan TNI itu sendiri yang mana keberadaan dan aktivitas seksual menyimpang yang dilakukan oleh Terdakwa selaku Prajurit TNI penyuka hubungan sesama jenis apabila dibiarkan akan mengganggu suasana ketertiban dan disiplin dalam kehidupan Prajurit di Kesatuan tempatnya bertugas. Seandainya Terdakwa tetap dipertahankan sebagai Prajurit TNI dikhawatirkan akan menggangu dan menggoyahkan sendi-sendi disiplin dan tata tertib dalam kehidupan Prajurit TNI yang selama ini sudah tertata dan terbina dengan baik.

\section{DAFTAR PUSTAKA}

Ali, M. (2015). Dasar-Dasar Hukum Pidana. Jakarta: Sinar Gratika. Moeljatno. 2015. Asas-asas Hukum Pidana. Jakarta: PT Rineka Cipta. Rahmanuddin Tomalili. 2019. Hukum Pidana. Yogyakarta: CV BUDI UTAMA.

Amrani, H., \& Ali, M. (2015). Sistem Pertanggungjawaban Pidana: Perkembangan dan Penerapan. Jakarta: PT Rajagrafindo Persada

Asyari, F, (2017), LGBT Dan Hukum Positif Indonesia, Jurnal Legalitas 2(2),

Bisri, I. (2013). Sistem Hukum Indonesia: Prinsip-Prinsip \& Implementasi Hukum di Indonesia. Jakarta: Rajawali Pers.

Ediwarman, (2016), Monograf Metodologi Penelitian Hukum, Yogyakarta: Genta Publisihing

Gunadi, I. (2014). Cepat \& Mudah Memahami Hukum Pidana. Jakarta: Prenadamedia Group.

Heniarti, D.D. (2017). Sistem Peradilan Militer Di Indonesia. Bandung: PT Refika Aditama.

Marlina, M. (2015). TINDAK PIDANA EKSPLOITASI SEKSUAL KOMERSIAL ANAK DI INDONESIA. JURNAL MERCATORIA, 8(2), 91-106. doi:https://doi.org/10.31289/mercatoria.v8i2.649

Purwoleksono, D.E., (2016). Hukum Pidana. Surabaya: Airlangga University Press.

Rahmi, A. (2018). URGENSI PERLINDUNGAN BAGI KORBANKEKERASAN SEKSUAL DALAM SISTEM PERADILAN PIDANA TERPADU BERKEADILAN GENDER. JURNAL MERCATORIA, 11(1), 37-60. doi:https://doi.org/10.31289/mercatoria.v11i1.1499

Saputra, R.Y.,. (2019), Penerapan Pasal 281 KUHP Tentang Tindak Pidana Asusila Yang Dilakukan Oleh Militer. (Studi Kasus Putusan Pengadilan Militer Nomor 127-K/PM.II-09/AD/VIII/2017)". Dalam Jurnal Hukum Adigama Vol 2 No 20. Putusan Perkara Hakim Militer Pengadilan Militer I-02 Medan Nomor Perkara 115-K/PM.1-02/AD/X/2019)

Schaffmeister, D., (2017). Hukum Pidana. Bandung: PT Citra Aditya Bakti.

Sigiro, D., Suhaidi, S., \& Affan, I. (2020). Perlindungan Hukum Bagi Korban Hubungan Seksual Sedarah (Studi Pada Unit Perlindungan Perempuan Dan Anak SATReskrim Polrestabes Medan). Journal of Education, Humaniora and Social Sciences (JEHSS), 3(1), 200-212. doi:https://doi.org/10.34007/jehss.v3i1.261

Simanjuntak, M., Januari S., dan Isnaini, (2010), Peran Polri dalam Penyidikan Tindak Pidana Kekerasan Seksual dalam Rumah Tangga (Studi di Unit Perlindungan Perempuan dan Anak Sat Reskrim Polresta Tebing Tinggi), Mercatoria, 3 (2):102-116

Soekanto, S. (2014). Faktor-Faktor Yang Mempengaruhi Penegakan Hukum. Jakarta..PT RajaGrafindo Persada.

Soekanto, S. (2018). Penelitian Hukum Normatif. Jakarta: Rajawali Pers.

Sunarso, H.S. (2015). Filsafat Hukum Pidana: Konsep, Dimensi, Dan Aplikasi. Jakarta: PT Raja Grafindo.

Trianto, J. “Persamaan Didepan Hukum Penyelesaian Tindak Pidana Kesusilaan Dalam Pasal 281 Kuhp Yang Dilakukan Oleh Prajurit Tni Dengan Warga Sipil Terkait Penegakan Hak Asasi Manusia". Dalam Lex Et Societatis Vol. 6 